\title{
Morphological, anatomical and physiological leaf traits of $Q$. ilex, $P$. latifolia, $P$. lentiscus, and $M$. communis and their response to Mediterranean climate stress factors
}

\author{
Loretta Gratani*, Rosangela Catoni and Laura Varone
}

\begin{abstract}
Background: Limitations to plant growth imposed by the Mediterranean climate are mainly due to carbon balance in response to stress factors. In particular, water stress associated to high air temperature and irradiance in summer causes a marked decrease in $\mathrm{CO}_{2}$ assimilation. Air temperature sensitivity of photosynthesis $\left(P_{\mathrm{N}}\right)$ differs from that of leaf respiration $\left(R_{\mathrm{D}}\right)$. $P_{\mathrm{N}}$ often decreases sharply at temperature above its optimum while $R_{\mathrm{D}}$ increases exponentially over short term rises in temperature. Nevertheless, the impact of water deficit on $R_{D}$ is still far from clear with reports in literature including decreases, maintenance or increases in its rates. The ratio $R_{\mathrm{D}} / P_{\mathrm{N}}$ can be considered a simple approach to leaf carbon balance because it indicates the percentage of photosynthates that is respired.

Results: The results underline different morphological, anatomical and physiological traits of the evergreen species co-occurring in the Mediterranean maquis which are indicative of their adaptive capability to Mediterranean stress factors. The ratio $R_{D} / P_{N}$ varies from $0.15 \pm 0.04$ in autumn, $0.24 \pm 0.05$ in spring through $0.29 \pm 0.15$ in winter to $0.46 \pm 0.11$ in summer. The lower $R_{D} / P_{N}$ in autumn and spring underlines the highest $P_{N}$ rates during the favorable periods when resources are not limited and leaves take in roughly three to five times more $\mathrm{CO}_{2}$ than they lose by respiration. On the contrary, the highest $R_{\mathrm{D}} / P_{\mathrm{N}}$ ratio in summer underlines the lowest sensitivity of respiration to drought. Among the considered species, Quercus ilex and Pistacia lentiscus have the largest tolerance to low winter temperatures while Phillyrea latifolia and Myrtus communis to drought, and Phillyrea latifolia the highest recovery capability after the first rainfall following drought.
\end{abstract}

Conclusions: The Mediterranean evergreen specie shows a different tolerance to Mediterranean climate stress factors. The predicted global warming might differently affect carbon balance of the considered species, with a possible change in Mediterranean shrublands composition in the long-term. Understanding the carbon balance of plants in water limited environments is crucial in order to make informed land management decisions. Moreover, our results underline the importance of including seasonal variations of photosynthesis and respiration in carbon balance models.

Keywords: Air temperature; Drought; Leaf respiration; LMA; Myrtus communis; Phillyrea latifolia; Photosynthesis; Pistacia lentiscus; Quercus ilex

* Correspondence: loretta.gratani@uniroma1.it

Department of Environmental Biology, Sapienza University of Rome, P.le A.

Moro, 5 00185, Rome, Italy 


\section{Background}

The Mediterranean Basin has long been recognized as a model region for studying global change effects on terrestrial ecosystems (Lavorel et al. 1998). Climatic models indicate that rainfall patterns are changing in the Mediterranean Basin as a consequence of the climate change, with a marked decrease up to $15-20 \%$ occurring mainly during summer, associated to an increase in the mean maximum air temperature of about $5.1^{\circ} \mathrm{C}$ by the end of the $21^{\text {st }}$ century (IPCC 2007). These changes will result in extended periods of soil moisture deficit (Hlavinka et al. 2009). Limitations to plant growth imposed by the Mediterranean climate are mainly due to plant carbon balance in response to stress factors (Galmés et al. 2007). In particular, water stress associated to high air temperatures and an excess of light during summer, may result in a chronic photo-inhibition or down-regulation of photosynthesis causing a marked decrease in $\mathrm{CO}_{2}$ assimilation (Zhou et al. 2010). Carbon balance depends on the ratio between photosynthesis and respiration (Lambers et al. 1998), and both these factors change in response to climatic conditions (Baldocchi and Amthor 2001). Nevertheless, they do not necessarily respond identically to changes in these conditions (De Boeck et al. 2007). Air temperature sensitivity of photosynthesis differs from that of respiration (Morison and Morecroft 2006; Way and Sage 2008; Shen et al. 2009). Photosynthesis often decreases sharply at temperatures above its optimum (Sage and Kubien 2007; Hüve et al. 2011), with most temperate species exhibiting a broad temperature optimum in the range of $15-30^{\circ} \mathrm{C}$ (Atwell et al. 1999; Larcher 2004), while leaf respiration increases exponentially over short term rises in temperature (Rodríguez-Calcerrada et al. 2011). In particular, the temperature sensitivity of leaf respiration is quantified using $\mathrm{Q}_{10}$ i.e. the proportional increase in respiration for every $10^{\circ} \mathrm{C}$ rise in temperature (Armstrong et al. 2006). Photosynthesis provides soluble sugar as substrates for leaf respiration (Atkin et al. 2007) and availability of respiratory substrates determines the effect of temperature on respiratory enzymes and consequently on respiration temperature sensitivity (Atkin et al. 2002; Rodríguez-Calcerrada et al. 2011). Respiration decrease depends partially on the photosynthesis decrease in response to water deficit (Gimeno et al. 2010). Under water stress a lower photosynthetic activity limits the soluble sugar availability (Pinheiro and Chaves 2011). A lower soluble sugar level may reduce the temperature sensitivity of respiration and then to cause a respiration decrease (RodríguezCalcerrada et al. 2011). Nevertheless, the impact of water deficits on leaf respiration is still far from clear, with reports in literature including decreases, maintenance, or increases in the rates of this process (Gimeno et al. 2010).
Since the magnitude of photosynthetic and respiratory acclimation varies among species, these processes are still poorly understood, especially under field conditions (Shen et al. 2009). In dry-land forests of the Mediterranean region, the rates of carbon loss by plant respiration often equal or exceed the rate of carbon uptake by photosynthesis during the year, except in spring and autumn, when air temperatures and water availability are favorable (Zaragoza-Castells et al. 2008; Gratani et al. 2008).

Mediterranean plant species are distributed along different gradients of water availability, according to their capacity to withstand drought (Medrano et al. 2009). Nevertheless, if dry season lasts too long, plant water deficit may negatively affect plant species capacity for carbon assimilation, as a result of the lowest photosynthetic rates and leaf surface area produced (Pereira et al. 2007). Carbon assimilation is also related to stomatal conductance with a strong impact on plant water use efficiency (i.e. the amount of water used per carbon gain) that links plant performance with water availability (Craven et al. 2013). The strength and direction of the relationship between water use efficiency and plant performance can illustrate interspecific differences in drought tolerance strategies (Craven et al. 2013).

Considering global change, variations in water supply will induce important changes in Mediterranean plant species that suffer of water scarcity, especially during drought (Llusiá et al. 2011). Different species can respond to global change by developing different mechanisms both at physiological and morphological levels. Nevertheless if the length or strength of the dry season increases, the distribution area of the species could shrink (Díaz-Barradas et al. 2010) and affect the composition of vegetation in the long-term (Gebrekirstos et al. 2011). Assessment of vegetation level vulnerability and climate change resilience require understanding of the diversity among plant species in the current vegetation, and of their growth strategies in response to fluctuating water availability (Dawson et al. 2009). A rapid adaptation to an increased aridity will be crucial for the future of many species in the Mediterranean region (Sánchez-Gómez et al. 2011). To predict how climate change might affect future Mediterranean species presence and distribution and, as a consequence, community structure and ecosystem functioning, it is essential to have a broad knowledge of which climatic factors are constraining plant species physiological traits, and how these constraints are manifested temporally (Llorens et al. 2003). Morphological adaptations as small, thick, layered leaves with high stomatal density of small size in many Mediterranean evergreen species could favor carbon gain profits over transpiration losses (Rotondi et al. 2003; Gratani and Varone 2004, 2006). Quercus ilex L., Phillyrea latifolia L., Pistacia lentiscus L., and Myrtus communis 
L. are evergreen shrub species largely distributed in the vegetation of the Mediterranean Basin. Q. ilex extends longitudinally from Portugal to Syria and latitudinally from Morocco to France (Valladares et al. 2000); it occurs in the Mediterranean maquis and forests, growing in different soil conditions and over a broad range of elevations, from the sea level to $1100 \mathrm{~m}$ a.s.l. (Khatouri 1992; Terradas and Savé 1992; Gratani et al. 2003). P. latifolia is a drought- and salt-stress-tolerant evergreen shrub species growing in the Mediterranean maquis, forests (Gratani and Bombelli 2000; Ogaya and Peñuelas 2003) and on seashore dunes, where excess soil salinity and salt spray are additional stress agents (Ogaya and Peñuelas 2003). P. lentiscus occurs in a wide variety of habitats, from open communities in garigue to closed ones in more mesic sites (Correia and Diaz Barradas 2000). M. communis is the only species of the Myrtaceae in the actual flora of the Mediterranean Basin (González-Varo 2010). It grows on fertile soils of warm habitats in the Mediterranean region (González-Varo et al. 2009) and in the maquis (Pignatti 1982).

The main objective of this research was to investigate morphological, anatomical and physiological leaf traits of Q. ilex, P. latifolia, P. lentiscus and M. communis and their involvement in carbon acquisition. Moreover, the ratio respiration to photosynthesis which is indicative of the capacity of plants to produce new biomass for growing and reproductive structures (Galmés et al. 2007; Millar et al. 2011) was analyzed over the year. Improving knowledge on carbon acquisition capability of the Mediterranean species will allow us to hypothesize their presence into the distribution area over the long-term, also in consideration of global change.

\section{Methods}

\section{Study site and plant material}

Experiments were carried out in the period from December 2009 to October 2010, on Q. ilex, P. latifolia, P. lentiscus, and $M$. communis shrubs (5 shrubs per species) growing in the open, under the same environmental conditions, at the Botanical Garden of Rome $\left(41^{\circ} 53^{\prime} 53^{\prime \prime} \mathrm{N}, 12^{\circ} 28^{\prime} 46^{\prime \prime} \mathrm{E}\right.$; $53 \mathrm{~m}$ a.s.l.). The selected shrubs had comparable size (height $=1.36 \pm 0.19 \mathrm{~m}$, mean value of the considered shrubs). During the study period the selected shrubs were not watered and they received only natural rain.

\section{Climate}

The climate of the study area was of the Mediterranean type: the mean minimum air temperature $\left(T_{\min }\right)$ of the coldest months (January and February) was $5.3 \pm 0.2^{\circ} \mathrm{C}$, the mean maximum air temperature $\left(T_{\max }\right)$ of the hottest months (July and August) was $30.9 \pm 0.2^{\circ} \mathrm{C}$, and the yearly mean air temperature $\left(T_{\mathrm{m}}\right)$ was $16.8 \pm 6.5^{\circ} \mathrm{C}$. Dry period was from the beginning of June to the end of
August (65.5 mm total rainfall of the period). Total annual rainfall was $708 \mathrm{~mm}$, most of it occurring in autumn and in winter (Data from UCEA for the years 1995 to 2010). During the study period $T_{\min }$ of the coldest month (January) was $3.8 \pm 3.1^{\circ} \mathrm{C}, T_{\max }$ of the hottest month (July) $34.0 \pm 2.2^{\circ} \mathrm{C}$, and total rainfall was $709 \mathrm{~mm}$, most of it occurring in winter.

\section{Anatomical leaf traits}

Leaf thickness $(\mathrm{L}, \mu \mathrm{m})$ was measured by leaf sections from fresh, fully expanded sun leaves (20 per species), collected at the end of September 2010 from the selected shrubs, and measured by light microscope. Stomatal density (SD, stomata $\mathrm{mm}^{-2}$ ) was measured from nail varnish impressions ( $\mathrm{n}=20$ per species) of the inferior lamina, according to Sack et al. (2003), each of them $0.5 \times$ $1.0 \mathrm{~cm}$, obtained by a Zeiss Axiocam MRc 5 digital camera (Carl Zeiss), with Axiovision AC software (Release 4.5). Stomatal pore length (SPL, $\mu \mathrm{m})$ and width (SPW, $\mu \mathrm{m})$ were measured on the same recorded digital images. Dimension of the stomata was used to calculate the equivalent area of the ellipsoid representing the stomatal pore area (SPA) by the following formula: $(\pi \times$ length $\times$ width) $/ 4$, according to Minnocci et al. (1995) and Bartolini et al. (1997).

\section{Morphological leaf traits}

Measurements of leaf morphological traits were carried out on fully expanded sun leaves ( $\mathrm{n}=20$ per species), collected at the end of September 2010. The following parameters were measured: projected fresh leaf surface area $\left(\mathrm{LA}, \mathrm{cm}^{2}\right)$ (excluding petioles), obtained by the Image Analysis System (Delta-T Devices, UK), and leaf dry mass $(\mathrm{DM}, \mathrm{mg})$, determined drying leaves at $80^{\circ} \mathrm{C}$ to constant mass. Leaf mass per unit leaf area (LMA, $\mathrm{mg} \mathrm{cm}{ }^{-2}$ ) was calculated by the ratio of DM and LA (Reich et al. 1992).

Leaf tissue density (LTD, $\mathrm{mg} \mathrm{cm}^{-3}$ ) was calculated by the ratio of LMA and leaf thickness (Wright and Westoby 2002).

\section{Gas exchange measurements}

Measurements of gas exchange were carried out using an infrared gas analyser (ADC LCA4, UK), equipped with a leaf chamber (PLC, Parkinson Leaf Chamber). Measurements were made on fully expanded sun leaves (10 leaves per species per each sampling occasion) during the study period.

Net photosynthetic rate $\left[P_{\mathrm{N}}, \mu \mathrm{mol}\left(\mathrm{CO}_{2}\right) \mathrm{m}^{-2} \mathrm{~s}^{-1}\right]$, photosynthetically active radiation [PAR, $\mu$ mol (photons) $\left.\mathrm{m}^{-2} \mathrm{~s}^{-1}\right]$, stomatal conductance $\left[g_{\mathrm{s}}, \mathrm{mol}\left(\mathrm{H}_{2} \mathrm{O}\right) \mathrm{m}^{-2} \mathrm{~s}^{-1}\right]$, leaf temperature $\left(T_{\mathrm{l}},{ }^{\circ} \mathrm{C}\right)$, and leaf chamber air temperature $\left(T_{\mathrm{ch}},{ }^{\circ} \mathrm{C}\right)$ were measured.

The $P_{\mathrm{N}} g_{\mathrm{s}}$, and $E$ rates shown were the mean of the maximum rates for the four days measurement per 
month, carried out in comparable weather conditions. During gas exchange measurements, the leaf to air vapour pressure deficit $\left(\mathrm{VPD}_{\text {leaf }} \mathrm{kPa}\right)$ was calculated according to Grantz (1990) as: VPD = es - ea, where es was saturated vapour pressure at leaf temperature and ea the air vapour pressure. The intrinsic water use efficiency [IWUE, $\mu \mathrm{mol}\left(\mathrm{CO}_{2}\right) \mathrm{mol}\left(\mathrm{H}_{2} \mathrm{O}\right)^{-1}$ ] was calculated as $P_{\mathrm{N}} / g_{\mathrm{s}}$ ratio, according to Medrano et al. (2009).

Measurements were carried out under natural conditions, on cloud - free days (PAR $\geq 1200 \mu \mathrm{mol} \mathrm{m} \mathrm{m}^{-2} \mathrm{~s}^{-1}$ ), in the morning, from 8.00 a.m. to 12.00 p.m., according to Reich et al. (1995).

On each sampling occasion, leaf respiration rate $\left[R_{\mathrm{D}}, \mu \mathrm{mol}\right.$ $\left.\left(\mathrm{CO}_{2}\right) \mathrm{m}^{-2} \mathrm{~s}^{-1}\right]$ measurements were carried out contemporary to $P_{\mathrm{N}}$ ones (on the same leaves) by darkening the leaf chamber with a black paper, according to Cai et al. (2005), for $30 \mathrm{~min}$ prior to each measurement to avoid transient post-illumination bursts of $\mathrm{CO}_{2}$ releasing (Atkin et al. $1998 \mathrm{a}, 1998 \mathrm{~b})$. The $R_{\mathrm{D}}$ rates shown were the mean of the maximum rates for the four days measured per month, carried out in comparable weather conditions. The ratio between $R_{\mathrm{D}}$ and $P_{\mathrm{N}}$ was also calculated. $\mathrm{Q}_{10}$ was calculated according to Rodríguez-Calcerrada et al. (2012) as: $\mathrm{Q}_{10}=$ $\mathbf{e}^{10 k}$ where $k$ is the slope of the linear regression between $T_{\mathrm{ch}}$ and the natural logarithm of $R_{\mathrm{D}}$ (Atkin et al. 2005).

\section{Statistics}

Differences in the considered variables were determined by the analysis of variance (ANOVA), and Tukey test for multiple comparisons, performed using a statistical software package (Statistica, Statsoft, USA). The regression analysis was carried out to evaluate correlations among the considered variables. The principal component analysis (PCA) was carried out in order to summarise the considered anatomical (L, SD, SPL, SPA), morphological (LMA, LTD) and physiological $\left(P_{\mathrm{N}}, R_{\mathrm{D}}, g_{\mathrm{s}}, E\right.$, IWUE) leaf traits into major components which explained their variation in the considered species.

\section{Results}

Anatomical and morphological leaf traits

Anatomical leaf traits of the considered species are shown in Table 1. L ranged from $311 \pm 10 \mu \mathrm{m}$ (M. communis) to
$419 \pm 25 \mu \mathrm{m}$ (P. latifolia). SD varied significantly $(\mathrm{p}<0.05)$ : $M$. communis had the highest SD $\left(508 \pm 82\right.$ stomata $\left.\mathrm{mm}^{-2}\right)$, followed by $Q$. ilex and P. lentiscus ( $419 \pm 18$ stomata $\mathrm{mm}^{-2}$, mean value), then by $P$. latifolia $\left(238 \pm 21\right.$ stomata $\left.\mathrm{mm}^{-2}\right)$. P. latifolia had the highest SPL and SPA $(19.5 \pm 2.6 \mu \mathrm{m}$, $170.3 \pm 31.3 \mu \mathrm{m}^{2}$, respectively), and $Q$. ilex the lowest ones $\left(9.1 \pm 1.9 \mu \mathrm{m}, 42.1 \pm 12.4 \mu \mathrm{m}^{2}\right.$, respectively). LMA varied from $9 \pm 1 \mathrm{mg} \mathrm{cm}^{-2}$ (M. communis) to $20 \pm 1 \mathrm{mg} \mathrm{cm}^{-2}$ (P. latifolia) (Table 2). Q. ilex had the highest LTD $\left(613 \pm 40 \mathrm{mg} \mathrm{cm}^{-3}\right)$ and $M$. communis the lowest one $\left(304 \pm 51 \mathrm{mg} \mathrm{cm}^{-3}\right)$.

\section{Seasonal gas exchange and leaf respiration variations}

Gas exchange and leaf respiration data of the considered species during the study period are shown in Figures 1 and 2 .

\section{Spring measurements}

During the study period all the considered species had the highest $P_{\mathrm{N}}$ and $g_{\mathrm{s}}$ in spring (March, April and May), peaking in May, when $T_{\max }$ was $23.8 \pm 3.0^{\circ} \mathrm{C}$, and water availability $113.8 \mathrm{~mm}$ (total rainfall of May). Q. ilex, P. lentiscus and $P$. latifolia had the significantly $(\mathrm{p}<0.05)$ highest $P_{\mathrm{N}}\left[15.4 \pm 0.2 \mu \mathrm{mol}\left(\mathrm{CO}_{2}\right) \mathrm{m}^{-2} \mathrm{~s}^{-1}\right.$, mean value measured in May] than $M$. communis $[10.7 \pm 0.7 \mu \mathrm{mol}$ $\left.\left(\mathrm{CO}_{2}\right) \mathrm{m}^{-2} \mathrm{~s}^{-1}\right]$.

$g_{\mathrm{s}}$ of $M$. communis $\left[0.11 \pm 0.04 \mathrm{~mol}\left(\mathrm{H}_{2} \mathrm{O}\right) \mathrm{m}^{-2} \mathrm{~s}^{-1}\right.$, in May] was 52\%, 39\%, and 35\% lower than P. latifolia, $P$. lentiscus and $Q$. ilex, respectively. $P$. lentiscus and P. latifolia had the lowest IWUE in May $[84 \pm 10$ and $68 \pm$ $6 \mu \mathrm{mol}\left(\mathrm{CO}_{2}\right) \mathrm{mol}\left(\mathrm{H}_{2} \mathrm{O}\right)^{-1}$, respectively] while $Q$. ilex and M. communis in April $\left[81 \pm 9\right.$ and $98 \pm 7 \mu \mathrm{mol}\left(\mathrm{CO}_{2}\right) \mathrm{mol}$ $\left(\mathrm{H}_{2} \mathrm{O}\right)^{-1}$, respectively].

A different $R_{\mathrm{D}}$ trend was observed in spring: $P$. lentiscus and Q. ilex $R_{\mathrm{D}}$ peaked in May $\left[3.7 \pm 0.3 \mu \mathrm{mol}\left(\mathrm{CO}_{2}\right) \mathrm{m}^{-2} \mathrm{~s}^{-1}\right.$, mean value], while $P$. latifolia in March $\left[R_{\mathrm{D}}=4.3 \pm 0.6 \mu \mathrm{mol}\right.$ $\left.\left(\mathrm{CO}_{2}\right) \mathrm{m}^{-2} \mathrm{~s}^{-1}\right]$. M. communis $R_{\mathrm{D}}$ was not significantly different from March to May $\left[2.7 \pm 0.1 \mu \mathrm{mol}\left(\mathrm{CO}_{2}\right) \mathrm{m}^{-2} \mathrm{~s}^{-1}\right.$, mean value of the three months]. $M$. communis had the highest $R_{\mathrm{D}} / P_{\mathrm{N}}$ ratio $(0.30 \pm 0.06$, mean of March, April and May), followed by $P$. latifolia $(0.23 \pm 0.08)$, P. lentiscus $(0.22 \pm 0.03)$ and Q. ilex $(0.20 \pm 0.05)$.

Table 1 Anatomical leaf traits at full leaf expansion of the considered species

\begin{tabular}{|c|c|c|c|c|c|}
\hline Species & $L(\mu \mathrm{m})$ & SPL $(\mu \mathrm{m})$ & $\mathrm{SPW}(\mu \mathrm{m})$ & SPA $\left(\mu \mathrm{m}^{2}\right)$ & SD (stomata $\mathrm{mm}^{-2}$ ) \\
\hline P. lentiscus & $378 \pm 54 a$ & $11.7 \pm 1.3 \mathrm{a}$ & $7.8 \pm 1.3 \mathrm{a}$ & $71.8 \pm 12.5 \mathrm{a}$ & $406 \pm 20 a$ \\
\hline P. latifolia & $419 \pm 25 a$ & $19.5 \pm 2.6 b$ & $11.1 \pm 1.3 b$ & $170.3 \pm 31.3 b$ & $238 \pm 21 b$ \\
\hline M. communis & $311 \pm 10 b$ & $10.5 \pm 2.0 \mathrm{ac}$ & $5.4 \pm 1.0 \mathrm{C}$ & $45.5 \pm 15.2 c$ & $508 \pm 82 c$ \\
\hline Q. ilex & $314 \pm 59 b$ & $9.1 \pm 1.9 \mathrm{C}$ & $5.9 \pm 0.6 c$ & $42.1 \pm 12.4 c$ & $432 \pm 34 a$ \\
\hline
\end{tabular}

L, leaf thickness; SPL, stomatal pore length; SPW, stomatal pore width; SPA, stomatal pore area; SD, stomatal density. Mean values ( \pm SE) are shown $(n=20)$. Mean values with the same letters are not significantly different (Tukey Test, $p \geq 0.05$ ). 
Table 2 Morphological leaf traits at full leaf expansion of the considered species

\begin{tabular}{lcccc}
\hline Species & DM $(\mathbf{m g})$ & LA $\left(\mathbf{c m}^{\mathbf{2}}\right)$ & LMA $\left(\mathbf{m g ~ c m}^{-\mathbf{2}}\right)$ & LTD $\left(\mathbf{m g ~ c m} \mathbf{~}^{-\mathbf{3}}\right)$ \\
\hline P. lentiscus & $229.7 \pm 53.4 \mathrm{a}$ & $11.7 \pm 2.3 \mathrm{a}$ & $19 \pm 2 \mathrm{a}$ & $521 \pm 57 \mathrm{a}$ \\
P. latifolia & $105.4 \pm 11.3 \mathrm{~b}$ & $5.2 \pm 0.4 \mathrm{~b}$ & $20 \pm 1 \mathrm{a}$ & $472 \pm 24 \mathrm{a}$ \\
M. communis & $31.5 \pm 7.8 \mathrm{c}$ & $3.5 \pm 0.4 \mathrm{c}$ & $9 \pm 1 \mathrm{~b}$ & $304 \pm 51 \mathrm{~b}$ \\
Q. ilex & $195.2 \pm 35.4 \mathrm{~d}$ & $10.1 \pm 1.6 \mathrm{~d}$ & $19 \pm 2 \mathrm{a}$ & $613 \pm 40 \mathrm{c}$ \\
\hline
\end{tabular}

DM, leaf dry mass; LA, projected leaf surface area; LMA, leaf mass per unit leaf area; LTD, leaf tissue density. Mean values $( \pm S E)$ are shown ( $n=20)$. Mean values with the same letters are not significantly different (Tukey Test, $\mathrm{p} \geq 0.05$ ).

\section{Winter measurements}

During winter (December, January and February) $P_{\mathrm{N}}, g_{\mathrm{s}}$ and $R_{\mathrm{D}}$ decreased in respect to the spring maximum, reaching the lowest rates in January $\left(T_{\min } 3.8 \pm 3.1^{\circ} \mathrm{C}\right.$; $118.2 \mathrm{~mm}=$ total rainfall of the month). In particular, Q. ilex had the lowest $P_{\mathrm{N}}$ decrease (68\% compared to the spring maximum) followed by $P$. lentiscus (82\%), M. communis (92\%) and P. latifolia (97\%). In the same month, Q. ilex had the significantly $(\mathrm{p}<0.05)$ highest $g_{\mathrm{s}}[0.06 \pm$ $0.01 \mathrm{~mol}\left(\mathrm{H}_{2} \mathrm{O}\right) \mathrm{m}^{-2} \mathrm{~s}^{-1}$, followed by $M$. communis $\left[0.03 \pm 0.01 \mathrm{~mol}\left(\mathrm{H}_{2} \mathrm{O}\right) \mathrm{m}^{-2} \mathrm{~s}^{-1}\right]$, P. lentiscus, and P. latifolia $\left[0.02 \pm 0.01 \mathrm{~mol}\left(\mathrm{H}_{2} \mathrm{O}\right) \mathrm{m}^{-2} \mathrm{~s}^{-1}\right.$, mean value].

Among the species the highest IWUE was measured in P. lentiscus $\left[127 \pm 22 \mu \mathrm{mol}\left(\mathrm{CO}_{2}\right) \mathrm{mol}\left(\mathrm{H}_{2} \mathrm{O}\right)^{-1}\right.$, mean of December, January and February] and the lowest one in P. latifolia $\left[45 \pm 22 \mu \mathrm{mol}\left(\mathrm{CO}_{2}\right) \mathrm{mol}\left(\mathrm{H}_{2} \mathrm{O}\right)^{-1}\right] . R_{\mathrm{D}}$ in January was, on an average, $84 \%$ lower than the spring maximum. $M$. communis and $P$. latifolia had the highest $R_{\mathrm{D}} / P_{\mathrm{N}}$ ratio $(0.61 \pm 0.02$ and $0.75 \pm 0.03$, respectively) and $Q$. ilex and P. lentiscus had the lowest one $(0.12 \pm$ 0.02 and $0.27 \pm 0.01$, respectively).

\section{Summer measurements}

In summer (June, July, August), $P_{\mathrm{N}}$ significantly decreased, reaching the lowest rates in August, when $T_{\max }$ was $32.3 \pm 2.0^{\circ} \mathrm{C}$, and the total rainfall of the month $4.4 \mathrm{~mm}$. In particular, $P_{\mathrm{N}}$ decreased, on an average, by $64 \%$ in $P$. lentiscus and Q. ilex, and $46 \%$ in P. latifolia and $M$. communis. IWUE was lower in P. lentiscus (24\%) and P. latifolia (1\%), and higher in M. communis and Q. ilex, (24\% and 33\%, respectively), compared to the spring values. $M$. communis had the lowest $g_{\text {s }}$ decrease (64\%) compared to the spring maximum, followed by Q. ilex (70\%), P. lentiscus (75\%), and P. latifolia (74\%).

$R_{\mathrm{D}}$ was $43 \%$ and $12 \%$ higher than the spring maximum in $P$. lentiscus and $P$. latifolia, respectively, while $R_{\mathrm{D}}$ was $13 \%$ lower than the spring maximum in $Q$. ilex. There were no significant $R_{\mathrm{D}}$ differences in $M$. communis between spring and summer measurements. P. lentiscus and $Q$. ilex had the highest $R_{\mathrm{D}} / P_{\mathrm{N}}$ rate $(0.94 \pm 0.05$ and $0.61 \pm 0.06$, respectively), followed by $P$. latifolia $(0.56 \pm$ $0.04)$, and M. communis $(0.43 \pm 0.02)$.

\section{Autumn measurements}

$P_{\mathrm{N}}$ recovered $64 \%$ of the spring maximum in $Q$. ilex, P. latifolia and M. communis (mean value), and $53 \%$ in P. lentiscus at the end of September $\left(T_{\max } 28.2 \pm 3.1^{\circ} \mathrm{C}\right)$ after the first rainfall $(22.9 \mathrm{~mm}$ from the middle to the end of September) following drought. $g_{\mathrm{s}}$ recovered $59 \%$ of the spring maximum in Q. ilex, $54 \%$ in M. communis, $44 \%$ in P. lentiscus, and $35 \%$ in P. latifolia.

IWUE ranged from $100 \pm 13 \mu \mathrm{mol}\left(\mathrm{CO}_{2}\right) \mathrm{mol}\left(\mathrm{H}_{2} \mathrm{O}\right)^{-1}$ in P. lentiscus to $125 \pm 13 \mu \mathrm{mol}\left(\mathrm{CO}_{2}\right) \mathrm{mol}\left(\mathrm{H}_{2} \mathrm{O}\right)^{-1}$ in $P$. latifolia. $P$. latifolia had the highest $R_{\mathrm{D}}[1.7 \pm 0.5 \mu \mathrm{mol}$ $\left.\left(\mathrm{CO}_{2}\right) \mathrm{m}^{-2} \mathrm{~s}^{-1}\right]$, followed by P. lentiscus and $Q$. ilex $[1.2 \pm$ $0.3 \mu \mathrm{mol}\left(\mathrm{CO}_{2}\right) \mathrm{m}^{-2} \mathrm{~s}^{-1}$, mean value], and $M$. communis $\left[0.6 \pm 0.1 \mu \mathrm{mol}\left(\mathrm{CO}_{2}\right) \mathrm{m}^{-2} \mathrm{~s}^{-1}\right]$. In October, $P_{\mathrm{N}}, g_{\mathrm{s}}$ increased compared to the rates monitored in September in all the considered species while $R_{\mathrm{D}}$ increased in $P$. latifolia, $P$. lentiscus and $M$. communis and decreased in $Q$. ilex.

In September, $P$. latifolia had the highest $R_{\mathrm{D}} / P_{\mathrm{N}}$ ratio $(0.17 \pm 0.02)$ followed by $P$. lentiscus $(0.15 \pm 0.04), Q$. ilex $(0.12 \pm 0.01)$ and $M$. communis $(0.09 \pm 0.02)$.

$\mathbf{Q}_{10}$

$Q$. ilex and $P$. latifolia showed the highest $\mathrm{Q}_{10}$ value $(1.78 \pm 0.01$, mean value) followed by $P$. lentiscus $(1.47 \pm 0.03)$ and $M$. communis $(1.44 \pm 0.02)$.

\section{Leaf to air vapour pressure deficit}

The seasonal VPD trend of the considered species is shown in Figure 3. The considered species had similar VPD trend with the lowest values in January ranging from $0.21 \pm 0.06 \mathrm{kPa}$ (in P. latifolia) to $0.33 \pm 0.05 \mathrm{kPa}$ (in $M$. communis). VPD increased from February (0.62 \pm $0.06 \mathrm{kPa}$, mean value) to August $(1.42 \pm 0.21 \mathrm{kPa}$, mean value) when $Q$. ilex had the highest VPD $(1.70 \pm 0.12$ $\mathrm{kPa})$ and $P$. lentiscus the lowest one $(1.20 \pm 0.09)$. In September and October VPD, on an average, decreased by $7 \%$ and $45 \%$ respectively, compared to August.

\section{Statistical analysis}

The results of the regression analysis showed a significant relationship between $R_{\mathrm{D}}$ and $T_{\mathrm{ch}}$ and between $g_{\mathrm{s}}$ and VPD (Figures 4 and 5). 


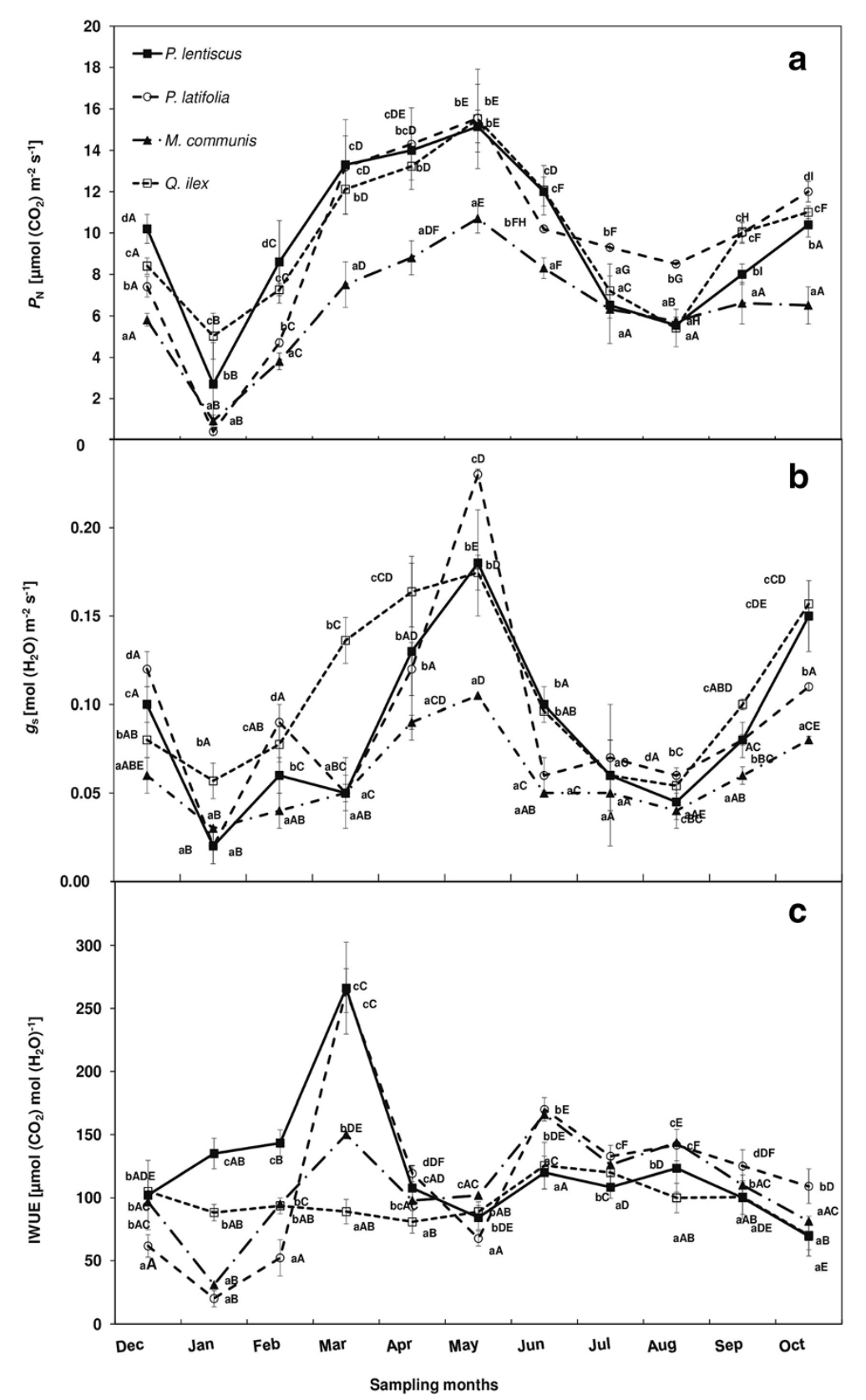

Figure 1 Trend of a) net photosynthetic rate $\left(P_{\mathrm{N}}\right)$, b) stomatal conductance $\left.\left(g_{\mathrm{s}}\right), \mathrm{c}\right)$ intrinsic water use efficiency (IWUE) of $P$. lentiscus (close squares), P. latifolia (open circles), M. communis (close triangles), and Q. ilex (open squares) during the study period. The mean values for each month $( \pm S E)$ are shown $(n=40$ leaves). Mean values with the same letters are not significantly different $(p \geq 0.05)$. Lowercase letters indicate the differences among the species for each month, capital letters indicate the intra-specific differences during the study period.

The PCA analysis extracted two factors accounting for $76 \%$ of the total variance among the considered species ( $48 \%$ and $28 \%$ for the $1^{\text {st }}$ and the $2^{\text {nd }}$ factor, respectively). The $1^{\text {st }}$ factor was related to physiological traits $\left(P_{\mathrm{N}}\right.$ in summer, $g_{\mathrm{s}}$ in spring, IWUE in spring and summer, $R_{\mathrm{D}}$ in summer and spring) and anatomical leaf traits (L, SPL, SPA and $\mathrm{SD})$. The $2^{\text {nd }}$ factor was mainly related to morphological leaf traits (LMA and LTD), and to $P_{\mathrm{N}}$ in winter and spring, and IWUE in winter. According to these results, the considered species were divided into three groups (Figure 6): the $1^{\text {st }}$ group included $P$. lentiscus and $Q$. ilex, the $2^{\text {nd }}$ group $P$. latifolia, and the $3^{\text {rd }}$ group $M$. communis.

\section{Discussion}

Knowledge of plant species response to limited soil moisture is important for providing insights into potential 


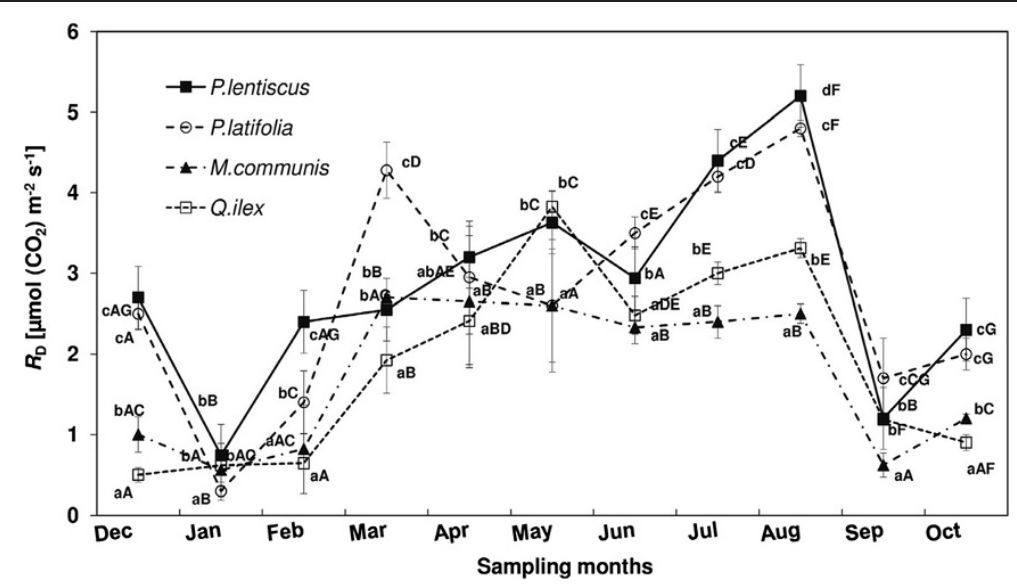

Figure 2 Leaf respiration $\left(R_{\mathrm{D}}\right)$ trend of $P$. lentiscus (close squares), P. latifolia (open circles), M. communis (close triangles) and $Q$. ilex (open squares) during the study period. The mean values for each month ( \pm SE) are shown ( $n=40$ leaves). Mean values with the same letters are not significantly different $(p \geq 0.05)$. Lowercase letters indicate the differences among the species for each month, capital letters indicate the intra-specific differences during the study period.

ecological impacts on wild populations (Wu et al. 2010) also in consideration of climate change scenarios which hypothesizes an increasing aridity in many regions worldwide (Canadell et al. 2007). Our results on the whole underline different morphological, anatomical and physiological leaf traits of the considered shrub species which are indicative of their adaptive capability to Mediterranean climate stress factors. Among the considered species, $Q$. ilex has the highest $P_{\mathrm{N}}$ in spring associated to the highest $R$ which may be related to the concomitance of vegetative activity (spring shoots production) and flowering (Gratani et al. 1996). Q. ilex has the largest tolerance to low winter air temperatures evidenced by the lowest $P_{\mathrm{N}}$ decrease (68\% of the maximum) and low $R_{\mathrm{D}}$ rates $(87 \%$ of the maximum). Under drought conditions, plants optimize carbon assimilation and minimize water loss by decreasing $g_{\mathrm{s}}$ (Medrano et al. 2002), and IWUE may be considered a good indicator of carbon assimilation optimization. Q. ilex has a high responsiveness to drought showing a high $g_{\mathrm{s}}$ decrease at the beginning of June ( $41 \%$ lower compared to the maximum) associated with a $22 \% P_{\mathrm{N}}$ decrease determining a $40 \%$ IWUE increase compared to the maximum. The responsive stomatal behaviour is also underlined by the significant relationship between $g_{\mathrm{s}}$ and VPD $\left(\mathrm{R}^{2}=0.46\right)$. As drought stress progresses in July, $Q$. ilex IWUE does not significantly increase because of $P_{\mathrm{N}}$ and $g_{\mathrm{s}}$ change to the same extent. At the highest drought intensity (August) IWUE decreases by $10 \%$ compared to June, due to a higher $P_{\mathrm{N}}$ decrease than $g_{s}$. Despite the high $P_{\mathrm{N}}$ decrease in August

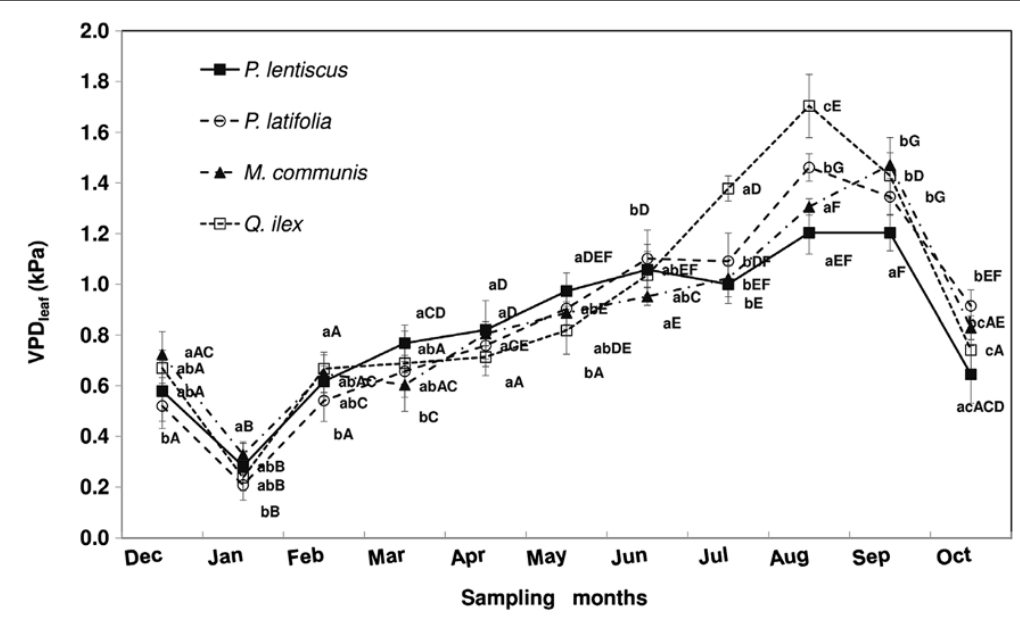

Figure 3 Leaf to air vapor pressure deficit $\left(\mathrm{VPD}_{\text {leaf }}\right.$ ) trend of $P$. lentiscus (close squares), P. latifolia (open circles), M. communis (close triangles) and $Q$. ilex (open squares) during the study period. The mean values for each month $( \pm \mathrm{SE})$ are shown ( $n=40$ leaves). Mean values with the same letters are not significantly different $(p \geq 0.05)$. Lowercase letters indicate the differences among the species for each month, capital letters indicate the intra-specific differences during the study period. 


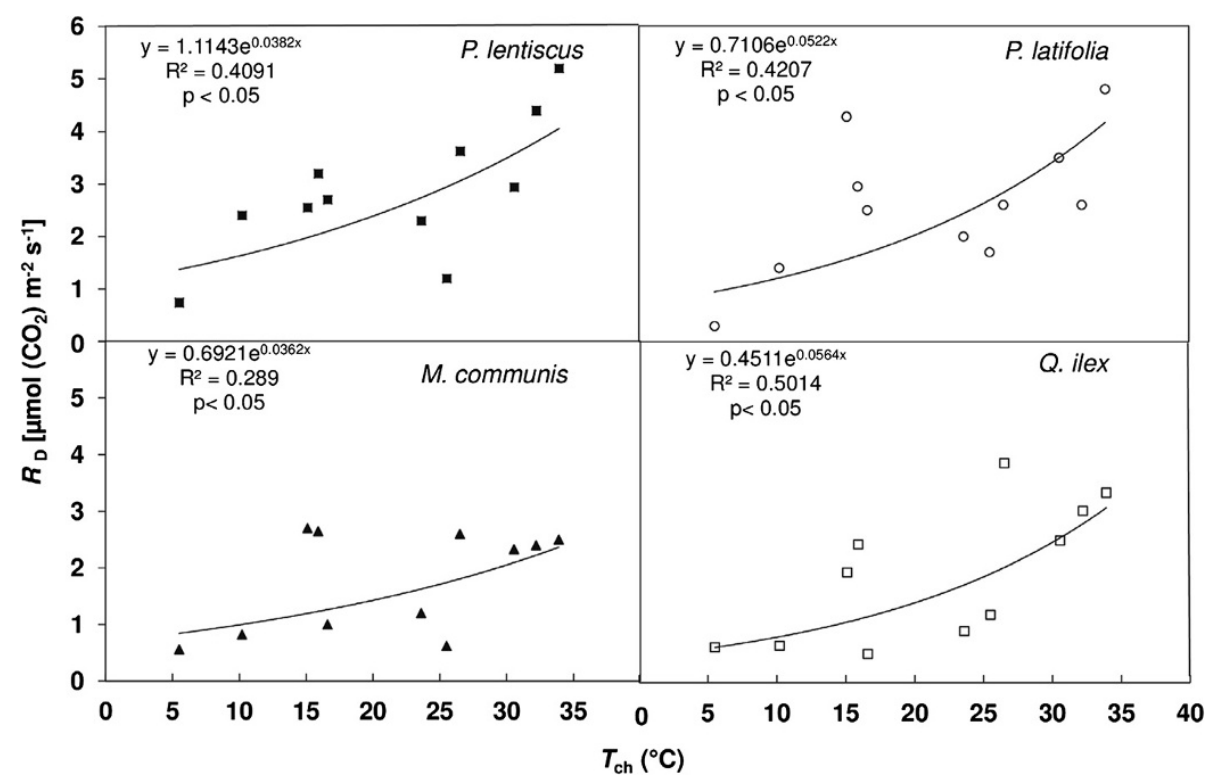

Figure 4 Regression analysis between leaf respiration $\left(R_{\mathrm{D}}\right)$ and leaf chamber air temperature $\left(T_{\mathrm{ch}}\right)$ for the considered species.

Regression equation, determination's coefficient $\left(R^{2}\right)$ and P-level are shown.

(by 65\% compared to the maximum), Q. ilex is able to recover $65 \%$ of the spring rates in September. Gratani and Varone (2003) underline the sufficiently high leaf water potential and relative water content during drought in Q. ilex. Moreover, the results underline that $Q$. ilex does not seem to suffer significant metabolic damage that could make a demand on respiratory products as drought stress progresses, according to the results of Rodríguez-Calcerrada et al. (2011). This is also pointed out by a $13 \% R_{\mathrm{D}}$ decrease in August compared to the spring rates. Due to the high $P_{\mathrm{N}}$ decrease, $Q$. ilex shows a relatively high $R_{\mathrm{D}} / P_{\mathrm{N}}$ ratio $(0.61 \pm 0.06)$ in August. The most important factor determining how negative the plant carbon balance becomes under water stress is the absolute and proportional change in $P_{\mathrm{N}}$ rates since drought has typically a greater proportional inhibitory effect on photosynthesis than on respiration thus, resulting in a higher $R_{\mathrm{D}} / P_{\mathrm{N}}$ ratio (Galmés et al. 2007). As regards leaf anatomy and morphology, Q. ilex high SD and low SPL and SPA, associated to a high LMA and LTD, contribute to an

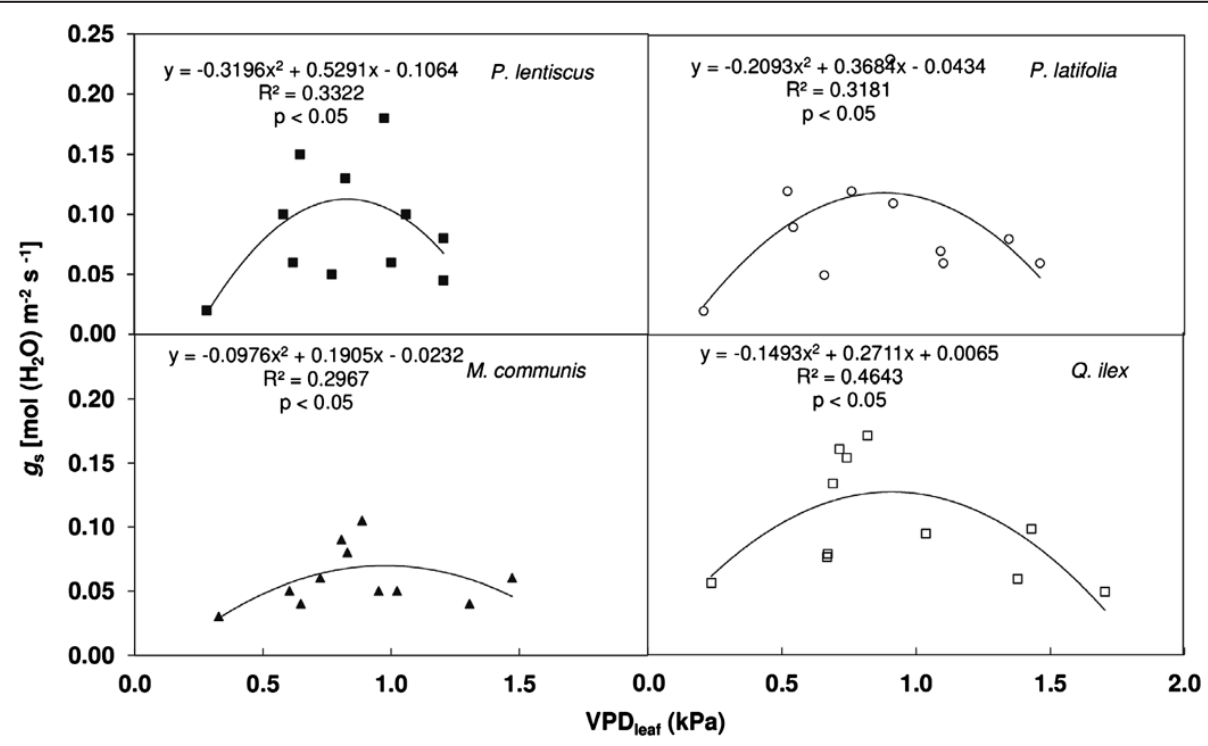

Figure 5 Regression analysis between stomatal conductance $\left(g_{s}\right)$ and leaf to air vapour pressure deficit $\left(\mathrm{VPD}_{\text {leaf }}\right)$ for the considered species. Regression equation, determination's coefficient $\left(R^{2}\right)$ and P-level are shown. 


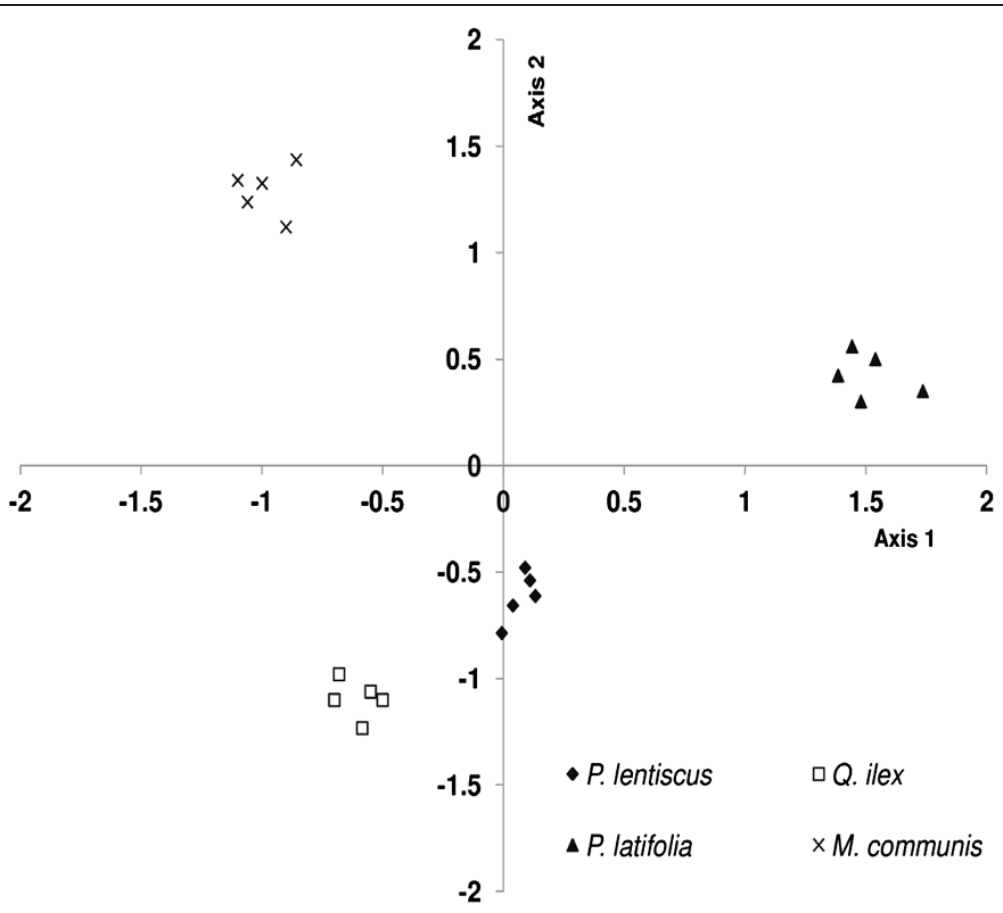

Figure 6 Principal component analysis (PCA) carried out using physiological traits in winter, spring and summer (photosynthetic rates stomatal conductance transpiration rates intrinsic water use efficiency and leaf respiration) and morphological and anatomical leaf traits (LMA, LTD, leaf thickness, stomatal density, stomatal pore length and stomatal pore area) for the considered species.

efficient control of gas exchange. Niinemets (2001) underlines that the adaptive significance of leaves characterised by thick cell walls and low fractions of intercellular air spaces (i.e. high LMA and LTD) lies in their large elastic module which upholds water flow from drying soils.

$P$. lentiscus strategy to stress factors is similar to that of Q. ilex (i.e. high $P_{\mathrm{N}}$ in spring and a relatively high $P_{\mathrm{N}}$ in winter associated to a high $R_{\mathrm{D}}$ ). In August $g_{\mathrm{s}}$ and $P_{\mathrm{N}}$ decrease by $72 \%$ and $63 \%$, respectively, and $R_{\mathrm{D}}$ increases by $43 \%$ resulting in a high $R_{\mathrm{D}} / P_{\mathrm{N}}$ ratio $(0.94 \pm 0.05)$.

The similar strategy of $P$. lentiscus and $Q$. ilex is also underlined by their similar IWUE values during the study period and their $P_{\mathrm{N}}$ recovery capability in September. Moreover, $P$. lentiscus shows a higher relationship between $g_{\mathrm{s}}$ and VPD $\left(\mathrm{R}^{2}=0.33\right)$ as well as $Q$. ilex. A higher $P_{\mathrm{N}}$ recovery capability might be related to the capacity of this species to have low leaf water potential and relative water content variations during the year (Gratani and Varone 2004). At morphological and anatomical levels, $P$. lentiscus is characterised by a high LMA and LTD. In particular, the larger SPL, SPW and SPA in $P$. lentiscus with respect to $Q$. ilex may be related to its origin from the semi-arid steppes of central Asia with an exceptionally hot summer and an exceptionally cold and dry winter (Blondel and Aronson 1999). Billing et al. (1971) and Cunningham and Read (2003) hypothesize that plant species which have originated in climates with more fluctuating temperatures may have a higher gas-exchange acclimation to air temperature than those originated in more constant climate. Thus, $Q$. ilex and P. lentiscus capability to maintain sufficiently high photosynthetic rates both in cold and drought stress periods seem to be related to their origin under a climate characterized by a pronounced seasonality.

Compared to the considered species, $P$. latifolia has the lowest $P_{\mathrm{N}}$ decrease in drought (45\% compared to the spring maximum) associated to a $74 \% g_{\mathrm{s}}$ decrease resulting in a high IWUE. The lower $R_{\mathrm{D}} / P_{\mathrm{N}}$ ratio $(0.56 \pm 0.04)$ in $P$. latifolia compared to $P$. lentiscus and $Q$. ilex, is due to the lowest $P_{\mathrm{N}}$ decrease in drought. The high $P$. latifolia photosynthetic recovery capacity in September (64\% of the maximum) after the first rainfall following drought attests to its greater drought tolerance through the maintenance of a high $P_{\mathrm{N}}$ rate even at low leaf water potential (Bombelli and Gratani 2003). Moreover, the high $P$. latifolia LMA, due to the presence of thick cell walls and sclereids (Gratani and Bombelli 1999) and the high LTD (i.e. a densely packed mesophyll cells with few air spaces, Gratani and Bombelli 2000) contribute to improve drought resistance by improving water use efficiency (Niinemets 2001) and limiting photochemical damage to the photosynthetic apparatus through the reduction of the incident irradiance (Jordan et al. 2005). On the contrary, the lower $P$. latifolia $P_{\mathrm{N}}$ in winter 
compared to the maximum underlines its lower tolerance to cold temperatures, according to the results of Ogaya and Peñuelas (2003), and Ogaya et al. (2011), also pointed out by the highest $R_{\mathrm{D}} / P_{\mathrm{N}}(0.75 \pm 0.03)$. The lowest $R_{\mathrm{D}}$ rates in January underline the limitation of the enzyme activity of the respiratory apparatus (i.e. glycolysis, the TCA cycle and mitochondrial electron transport chain) (Atkin and Tjoelker 2003).

M. communis has a physiological response to drought similar to that of $P$. latifolia, which may be related to their common origin in the dry tropics of the continental Africa and adjacent regions (Blondel and Aronson 1999). $M$. communis has a low $P_{\mathrm{N}}$ decrease (by $46 \%$ ) during drought associated to stable $R_{\mathrm{D}}$ rates which determine a lower $R_{\mathrm{D}} / P_{\mathrm{N}}$ ratio $(0.43 \pm 0.02)$. In winter a $92 \% P_{\mathrm{N}}$ decrease associated to a $79 \% R_{\mathrm{D}}$ decrease results in a higher $R_{\mathrm{D}} / P_{\mathrm{N}}$ ratio $(0.61 \pm 0.02)$. Hernández et al. (2010) underline that $M$. communis has a low capacity to transport water from roots to leaves also under water availability. Gratani et al. (1980) show its low biomass production capability respect to other Mediterranean shrubs which are pointed out by the significant lowest $M$. communis $P_{\mathrm{N}}$ rates during the study period compared to the other considered species. Moreover, the low stomatal control of $M$. communis is pointed out by a lower relationship between $g_{s}$ and VPD $\left(\mathrm{R}^{2}=0.29\right)$. Despite the highest SD, M. communis has a very small SPL and SPW which could explain the low $g_{s}$. The lower LMA and LTD M. communis with respect to P. latifolia underline a lower leaf consistency. The above considerations are confirmed by the PCA showing a higher similarity between $Q$. ilex and $P$. lentiscus compared to $P$. latifolia and $M$. communis.

Chu et al. (2011) suggest that $R_{\mathrm{D}} / P_{\mathrm{N}}$ ratio can be considered as a simple approach to leaf carbon balance because it indicates the percentage of photosynthates that is respired. Our results show that $R_{\mathrm{D}} / P_{\mathrm{N}}$ ratio of the considered species, calculated over the study period, varies from $0.15 \pm 0.04$ in autumn, $0.24 \pm 0.05$ in spring, through $0.29 \pm 0.15$ in winter to $0.46 \pm 0.11$ in summer, and it is indicative of the different sensitivity of both $R_{\mathrm{D}}$ and $P_{\mathrm{N}}$ to water availability and air temperature changes, according to results of Zaragoza-Castells et al. (2008). The low $R_{\mathrm{D}} / P_{\mathrm{N}}$ ratio in autumn and spring of the considered Mediterranean evergreen species (i.e. during vegetative activity) underlines the highest $P_{\mathrm{N}}$ rates during the favorable periods, when resources are not limited, and leaves take in roughly three to five times more $\mathrm{CO}_{2}$ than they lose by dissimilatory processes during the same period of time (Larcher 2003). On the contrary, the highest $R_{\mathrm{D}} / P_{\mathrm{N}}$ ratio in summer underlines the lower sensitivity of respiration to drought (Atkin and Macherel 2009) that is indicative of a higher proportion of fixed carbon which is respired at elevated temperature (Gratani et al. 2011;
Riikonen et al. 2012). Thus, summer drought can reduce the carbon assimilation because of $R_{\mathrm{D}}$ rates increasing more than $P_{\mathrm{N}}$ rates.

It is known that over short-term rises in temperature, $R_{\mathrm{D}}$ increases exponentially but the seasonal temperature sensitivity of $R_{\mathrm{D}}$ is often lower than that observed over hours, a phenomenon known as thermal acclimation (Rodríguez-Calcerrada et al. 2012). This phenomenon involves adjustments in $R_{\mathrm{D}}$ rates to compensate for changes in air temperature (Atkin et al. 2000). In particular, acclimation of $R_{\mathrm{D}}$ to high temperatures can result in a lower slope (i.e. lower $\mathrm{Q}_{10}$ ) for the temperatureresponse curve of acclimated tissue (Atkin et al. 2000). Among the considered species, M. communis has the higher acclimation to high temperatures compared to the other species pointed out by the lower $\mathrm{Q}_{10}$ value $(1.44 \pm 0.02)$ and by more stable $R_{\mathrm{D}}$ rates during the year. There is growing evidence that acclimation of $R_{\mathrm{D}}$ to heat and drought reflects the metabolic downregulation that reduces carbon depletion and helps plants to grow and survive in Mediterranean-type environments (Rodríguez-Calcerrada et al. 2010, 2011). Understanding the function of plant species in water limited environments is crucial in order to make informed land management decisions (Maseyk et al. 2008). Moreover, under a Mediterranean type of climate, our results underline the importance of including seasonal variations of photosynthesis and respiration in carbon balance models.

\section{Conclusions}

Limitations to plant growth imposed by the Mediterranean climate are mainly due to carbon balance in response to stress factors. In particular, water stress associated to high air temperature and irradiance in summer causes a marked decrease in $\mathrm{CO}_{2}$ assimilation. The results underline the response of the evergreen species co-occurring in the Mediterranean maquis to Mediterranean stress factors. In particular, the lower $R_{\mathrm{D}} / P_{\mathrm{N}}$ in autumn and spring underlines the highest $P_{\mathrm{N}}$ rates during the favorable periods while the highest $R_{\mathrm{D}} / P_{\mathrm{N}}$ ratio in summer shows the lower sensitivity of respiration to drought. Among the considered species, $Q$. ilex and P. lentiscus have the largest tolerance to low winter temperatures while $P$. latifolia and $M$. communis to drought. Among the considered species, $M$. communis has the higher acclimation to high temperatures compared to the other species and this is underlined by the lower $\mathrm{Q}_{10}$ value and the more stable $R_{\mathrm{D}}$ rates during the year. The predicted global warming might differently affect carbon balance of the considered species, with a possible change in Mediterranean shrublands composition in the long term.

\section{Abbreviations}

DM: Leaf dry mass; $g_{s}$ : Stomatal conductance; L: Leaf thickness; LA: Leaf surface area; LMA: Leaf mass area; LTD: Leaf tissue density; SD: Stomatal 
density; SPA: Stomatal pore area; SPL: Stomatal pore length; SPW: Stomatal pore width; $P_{\mathrm{N}}$ : Net photosynthetic rate; $R_{\mathrm{D}}$ : Respiration rate; $T_{\mathrm{ch}}$ : Leaf chamber air temperature; $T_{i}$ Leaf temperature; IWUE: Intrinsic water use efficiency.

\section{Competing interests}

The authors declare that they have no competing interests.

\section{Authors' contributions}

LG wrote the manuscript. RC carried out the experimental research and contributed to statistical analysis. LV carried out the experimental research and statistical analysis. All authors read and approved the final manuscript.

\section{Acknowledgements}

This paper was supported by the grants from Ministry of Agricultural, alimentary and Forestry politicians (MIPAF) for the years 2007-2010.

\section{Received: 4 March 2011 Accepted: 1 April 2013}

Published: 17 September 2013

\section{References}

Armstrong AF, Logan DC, Atkin OK (2006) On the development dependence of leaf respiration: responses to short- and long-term changes in growth temperature. Amer J Bot 93:1633-1639

Atkin OK, Macherel D (2009) The crucial role of plant mitochondria in orchestrating drought tolerance. Ann Bot 103:581-597

Atkin OK, Tjoelker MG (2003) Thermal acclimation and the dynamic response of plant respiration to temperature. Trends Plant Sci 8:343-351

Atkin OK, Evans JR, Ball MC, Siebke K (1998a) Relationship between the inhibition of leaf respiration by light and enhancement of leaf dark respiration following light treatment. Aust J Plant Physiol 25:437-433

Atkin OK, Evans JR, Ball MC, Siebke K, Pons TL, Lambers H (1998b) Light inhibition of leaf respiration: the role of irradiance and temperature. In: Moller IM, Gardestrom P, Gliminius K, Glaser E (ed) Plant Mitochondria: from Gene to Function. Backhuys Publishers, Leiden, pp 567-574

Atkin OK, Edwards EJ, Loveys BR (2000) Response of root respiration to changes in temperature and its relevance to global warming. New Phytol 147:141-154

Atkin OK, Zhang QS, Wiskich JT (2002) Effect of temperature on rates of alternative and cytochrome pathway respiration and their relationship with the redox poise of the quinine pool. Plant Physiol 128:212-222

Atkin OK, Bruhn D, Tjoelker MG (2005) Response of plant respiration to changes in temperature: mechanisms and consequences of variations in $Q_{10}$ values and acclimation. In: Lambers H, Ribas- Carbó M (ed) Plant Respiration. From Cell to Ecosystem. Springer, Dordrecht, The Netherlands, pp 95-135

Atkin OK, Scheurwater I, Pons TL (2007) Respiration as a percentage of daily photosynthesis in whole plants is homeostatic at moderate, but not high, growth temperatures. New Phytol 174:367-380

Atwell BJ, Kriedemann PE, Turnbull CGN (ed) (1999) Plants in Action. Adaptation in Nature, Performance in Cultivation. Macmillan Education Australia Pty Ltd, South Yarra

Baldocchi DD, Amthor JS (2001) Canopy photosynthesis. In: Roy J, Saugier B, Mooney HA (ed) Terrestrial global productivity. Academic Press, San Diego, CA, USA, pp 9-31

Bartolini S, Minnocci A, Vitagliano C (1997) Influence of temperature on morphoanatomic characteristics of "Trebbiano" gravepine leaves. Agricoltura Mediterranea 127:37-43

Billing WD, Godfrey PJ, Chabot BF, Bourque DP (1971) Metabolic acclimation to temperature in arctic and alpine ecotypes of Oxyria digyna. Arct Antarct Apl Res 3:277-289

Blondel J, Aronson J (ed) (1999) Biology and Wildlife of the Mediterranean Region. Oxford University Press, New York. 328 pp

Bombelli A, Gratani L (2003) Interspecific differences of leaf gas exchange and water relations of three evergreen Mediterranean shrub species. Photosynthetica 41:619-625

Cai ZQ, Slot M, Fan ZX (2005) Leaf development and photosynthetic properties of three tropical species with delayed greening. Photosynthetica 43:91-98

Canadell JG, Pataki DE, Pitelka LF (ed) (2007) Terrestrial ecosystems in a changing World. Springer, Berlin

Chu Z, Yijun L, Chang J, Wang M, Jiang H, He J, Peng C, Ge Y (2011) Leaf respiration/photosynthesis relationship and variation: an investigation of 39 woody and herbaceous species in east subtropical China. Trees 25:301-310
Correia O, Diaz Barradas MC (2000) Ecophysiological differences between male and female plants of Pistacia lentiscus L. Plant Ecol 149:131-142

Craven D, Hall JS, Ashton MS, Berlyn GP (2013) Water-use efficiency and wholeplant performance of nine tropical tree species at two sites with contrasting water availability in Panama. Trees 27:639-653

Cunningham SC, Read J (2003) Do temperate rainforest trees have a greater ability to acclimate to changing temperatures than tropical rainforest trees? New Phytol 157:55-64

Dawson IK, Lengkeek A, Weber JC, Jamnadas R (2009) Managing genetic variation in tropical trees: linking knowledge with action in agroforestry ecosystem for improved conservation and enhanced livelihood. Biodivers Conserv 18:969-986

De Boeck HJ, Lemmens CMHM, Vicca S, den Berge JV, Van Dongen S, Janssens IA, Ceulemans R, Nijs I (2007) How do climate warming and species richness affect $\mathrm{CO}_{2}$ fluxes in experimental grasslands? New Phytol 175:512-522

Díaz-Barradas MC, Zunzunegui M, Ain-Lhout F, Jáuregui J, Boutaleb S, ÁlvarezCansino L, Esquivias MP (2010) Seasonal physiological responses of Argania spinosa tree from Mediterranean to semi-arid climate. Plant Soil 337:217-231

Galmés J, Ribas-Carbó M, Medrano H, Flexas J (2007) Response of leaf respiration to water stress in Mediterranean species with different growth forms. J Arid Environ 68:206-222

Gebrekirstos A, van Noordwijk M, Neufeldt H, Mitlöhner R (2011) Relationships of stable carbon isotopes, plant water potential and growth: an approach to asses water use efficiency and growth strategies of dry land agroforestry species. Trees 25:195-102

Gimeno TE, Sommerville KE, Valladares F, Atkin OK (2010) Homeostasis of respiration under drought and its important consequences for foliar carbon balance in a drier climate: insights from two contrasting Acacia species. Funct Plant Biol 37:323-333

González-Varo JP (2010) Fragmentation, habitat composition and the dispersal/ predation balance in interactions between the Mediterranean myrtle and avian frugivores. Ecography 33:185-197

González-Varo JP, Rafael G, Albaladejo RG, Aparicio A (2009) Mating patterns and spatial distribution of conspecific neighbours in the Mediterranean shrub Myrtus communis (Myrtaceae). Plant Ecol 203:207-215

Grantz DA (1990) Plant response to atmospheric humidity. Plant Cell Environ 13:667-679

Gratani L, Bombelli A (1999) Leaf anatomy, inclination, and gas exchange relationships in evergreen sclerophyllous and drought semideciduous shrub species. Photosynthetica 37:573-585

Gratani L, Bombelli A (2000) Correlation between leaf age and other leaf traits in three Mediterranean maquis shrub species: Quercus ilex, Phillyrea latifolia and Cistus incanus. Environ Exp Bot 43:141-153

Gratani L, Varone L (2003) Drought-adaptive responses of the Mediterranean shrub species. Atti del Tredicesimo Congresso Nazionale della S.IT.E. Como (I), 8-10 Settembre. In: Processing of the 13th National Congress of the Italian Ecology Society (S.IT.E). , Como, Italy, pp 8-10

Gratani L, Varone L (2004) Adaptive photosynthetic strategies of the Mediterranean maquis species according to their origin. Photosynthetica 42:551-558

Gratani L, Varone L (2006) Long-time variations in leaf mass and area of Mediterranean evergreen broad-leaf and narrow-leaf maquis species. Photosynthetica 44:161-168

Gratani L, Amadori M, Veri L, Bruno F, Porri M (1980) Determinazione di un metodo di stima della Biomassa nella macchia di Castelporziano (Lazio). Annali di Botanica XXXXI 1:131-151

Gratani L, Tisi F, Crescente MF, Pesoli P, Larcher W (1996) Phenology, leaf morphology and trends in $\mathrm{CO}_{2}$ uptake of Quercus ilex $\mathrm{L}$. in the climax area and at its northern distribution limit in Italy. Arch Geobot 2:13-18

Gratani L, Meneghini M, Pesoli P, Crescente MF (2003) Structural and functional plasticity of Quercus ilex seedlings of different provenances in Italy. Trees 17:515-521

Gratani L, Varone L, Catoni R (2008) Relationship between net photosynthesis and leaf respiration in Mediterranean evergreen species. Photosynthetica 46:567-573

Gratani L, Catoni R, Varone L (2011) Photosynthetic and leaf respiration activity of Malcolmia littorea (L.) R. Br. in response to air temperature. Photosynthetica 49:65-74

Hernández El, Vilagrosa A, Pausas JG, Bellot J (2010) Morphological traits and water use strategies in seedlings of Mediterranean coexisting species. Plant Ecol 207:233-244 
Hlavinka P, Trnka P, Semeradova D, Dubrosky M, Zalud Z, Mozny M (2009) Effect of drought on yield variability of key crops in Czech Republic. Agric Forest Meteorol 149:431-442

Hüve K, Bichele I, Rasulovo B, Niinemets Ü (2011) When it is too hot for photosynthesis: heat-induced instability of photosynthesis in relation to respiratory burst, cell permeability changes and $\mathrm{H}_{2} \mathrm{O}_{2}$ formation. Plant Cel Environ 34:113-126

IPCC (2007) Climate change 2007: impacts, adaptation and vulnerability. Fourth Assessment Report. Summary for Policymakers. Working Group II. University Press, Cambridge

Jordan GJ, Dillon RA, Weston PH (2005) Solar radiation as a factor in the evolution of scleromorphic leaf anatomy in Proteaceae. Am J Bot 92:789-796

Khatouri M (1992) Growth and yield of young Quercus ilex coppice stands in the Tafferte forest (Morocco). Vegetatio 99-100:77-82

Lambers H, Chapin FS, III, Pons TL (ed) (1998) Plant Physiological Ecology. Springer, New York

Larcher W (ed) (2003) Physiological plant ecology. Springer, Heidelberg, p 513

Larcher W (ed) (2004) Physiological Plant Ecology: Ecophysiology and Stress Physiology of Functional Groups, 4th edition. Springer-Verlag, Berlin, Germany

Lavorel S, Canadell J, Rambal S, Terradas J (1998) Mediterranean terrestrial ecosystem: research priorities on global change effects. Global Ecol Biogeogr Letters 7:157-166

Llorens L, Peñuelas J, Filella I (2003) Diurnal and seasonal variations in the photosynthetic performance and water relations of two co-occurring Mediterranean shrubs, Erica multiflora and Globularia alypum Physiol. Plantarum 118:84-95

Llusiá J, Peñuelas J, Alessio GA, Ogaya R (2011) Species-specific, seasonal, interannual, and historically-accumulated changes in foliar terpene emission rates in Phillyrea latifolia and Quercus ilex submitted to rain exclusion in the Prades mountains (Catalonia). Russ J Plant Physl 58(1):126-132

Maseyk K, Grünzweig JM, Rotenberg E, Yakir D (2008) Respiration acclimation contributes to high carbon use efficiency in a seasonally dry pine forest. Global Change Biol 14:1553-1567

Medrano H, Escalona JM, Bota J, Gulías J, Flexas J (2002) Regulation of photosynthesis of $C_{3}$ plants in response to progressive drought: the interest of stomatal conductance as a reference parameter. Ann Bot (Lond) 89:895-905

Medrano H, Flexas J, Gálmes J (2009) Variability in water use efficiency at the leaf level among Mediterranean plants with different growth forms. Plant Soil 317:17-29

Millar AH, Whelan J, Soole KL, Day DA (2011) Organization and regulation of mitochondrial respiration in plants. Annu Rev Plant Biol 62:79-104

Minnocci A, Panicucci A, Vitagliano C (1995) Gas exchange and morphological stomatal parameters in olive plants exposed to ozone. In: Lorenzini G, Soldatini GF (ed) Responses of plants to air pollution: biological and economic aspects. Agricoltura Medieterranea (Special Volume), Pacini, Pisa, pp 77-81

Morison JIL, Morecroft MD (2006) Plant growth and climate change. Significance of temperature in plant life. Blackwell Publishing, Boston, MA, U.S.A

Niinemets Ü (2001) Global-scale climatic controls of leaf dry mass per area, density, and thickness in trees and shrubs. Ecology 82(2):453-469

Ogaya R, Peñuelas J (2003) Comparative seasonal gas exchange and chlorophyll fluorescence of two dominant woody species in a Holm Oak Forest. Flora 198:132-141

Ogaya R, Peñuelas J, Asensio D, Llusià J (2011) Chlorophyll fluorescence responses to temperature and water availability in two co-dominant Mediterranean shrub and tree species in long-term field experiment simulating climate change. Environ Exp Bot 71:123-127

Pereira JS, Mateus JA, Aires LM, Pita G, Pio C, David JS, Andrade V, Banza J, David TS, Paço TA, Rodrigues A (2007) Net ecosystem carbon exchange in three contrasting Mediterranean ecosystem - the effect of drought. Biogeosciences 4:791-802

Pignatti S (ed) (1982) Flora d'Italia. Edagricole, Bologna

Pinheiro C, Chaves MM (2011) Photosynthesis and drought: can we make metabolic connections from available data? J Exp Bot 62(3):869-882

Reich PB, Walters MB, Ellsworth DS (1992) Leaf life-span in relation to leaf, plant and stand characteristics among diverse ecosystem. Ecol Monogr 62:365-392

Reich PB, Kloeppel BD, Ellsworth DS, Walters MB (1995) Different photosynthesisnitrogen relations in deciduous hardwood and evergreen coniferous tree species. Oecologia 104:24-30
Riikonen J, Kontunen-Soppela S, Ossipov V, Tervahauta A, Tuomainen M, Oksanen E, Vapaavuori E, Heinonen J, Kivimäenpää M (2012) Needle metabolome, freezing tolerance and gas exchange in Norway spruce seedlings exposed to elevated temperature and ozone concentration. Tree Physiol 32:1102-1112

Rodríguez-Calcerrada J, Atkin OK, Robson TM, Zaragoza-Castells J, Gil L, Aranda I (2010) Thermal acclimation of leaf dark respiration of beech seedlings experiencing summer drought in high and low light environments. Tree Physiol 30:214-224

Rodríguez-Calcerrada J, Jaeger C, Limousin JM, Ourcivall JM, Joffre R, Rambal S (2011) Leaf $\mathrm{CO}_{2}$ efflux is attenuated by acclimation of respiration to heat and drought in a Mediterranean tree. Funct Ecol 25:983-995

Rodríguez-Calcerrada J, Limousin J-M, Martin-StPaul NK, Jaeger C, Rambal S (2012) Gas exchange and leaf aging in an evergreen oak: causes and consequences for leaf carbon balance and canopy respiration. Tree Physiol 32:464-477

Rotondi A, Rossi F, Asunis C, Cesaraccio C (2003) Leaf xeromorphic adaptations of some plants of a coastal Mediterranean macchia ecosystem. J Medit Ecol 4 (3/4):25-35

Sack L, Grubb PJ, Marañón T (2003) The functional morphology of juvenile plants tolerant of strong summer drought in shaded firest understories in sourthern Spain. Plant Ecol 168:247-259

Sage RF, Kubien DS (2007) The temperature response of $C_{3}$ and $C_{4}$ photosynthesis. Plant Cell Environ 30:1086-1106

Sánchez-Gómez D, Velasco-Conde T, Cano-Martín FJ, Guevara MA, Cervera MT, Aranda I (2011) Inter-clonal variation in functional traits in response to drought for a genetically homogeneous Mediterranean conifer. Environ Exp Bot 70:104-109

Shen H, Klein JA, Zhao X, Tang Y (2009) Leaf photosynthesis and simulated carbon budget of Gentiana straminea from a decade-long warming experiment. J Plant Ecology 2(4):207-216

Terradas J, Savé R (1992) The influence of summer and winter stress and water relationships on the distribution of Quercus ilex L. Vegetatio 100:137-145

Valladares F, Martinez-Ferri E, Balaguer L, Perez-Corona E, Manrique E (2000) Low leaf-level response to light and nutrients in Mediterranean evergreen oaks: a conservative resource-use strategy? New Phytol 148:79-91

Way DA, Sage RF (2008) Thermal acclimation of photosynthesis in black spruce (Picea mariana (Mill.) BSP). Plant Cell Environ 31:1250-1262

Wright IJ, Westoby M (2002) Leaves at low versus high rainfall: coordination of structure, lifespan and physiology. New Phytol 155:403-416

Wu CA, Lowry DB, Nutter LI, Willis JH (2010) Natural variation for drought-response traits in the Mimulus guttatus species complex. Oecologia 162:23-33

Zaragoza-Castells J, Sánchez-Gómez D, Hartley IP, Matesanz S, Valladares F, Lloyd J, Atkin OK (2008) Climate-dependent variations in leaf respiration in a dry-land, low productivity Mediterranean forest: the importance of acclimation in both high-light and shaded habitats. Funct Ecol 22:172-184

Zhou HH, Chen YN, Li WH, Chen YP (2010) Photosynthesis of Populus euphratica in relation to groundwater depths and high temperature in arid environment, northwest China. Photosynthetica 48(2):257-268

\section{doi:10.1186/1999-3110-54-35}

Cite this article as: Gratani et al:: Morphological, anatomical and physiological leaf traits of $Q$. ilex, $P$. latifolia, $P$. lentiscus, and $M$. communis and their response to Mediterranean climate stress factors. Botanical Studies 2013 54:35.

\section{Submit your manuscript to a SpringerOpen ${ }^{\circ}$ journal and benefit from:}

- Convenient online submission

Rigorous peer review

- Immediate publication on acceptance

- Open access: articles freely available online

- High visibility within the field

- Retaining the copyright to your article

Submit your next manuscript at $>$ springeropen.com 